\title{
Company's sales simulation based on the use of SWOT analysis and Ishikawa charts
}

\author{
Sergey Ivanov ${ }^{1, *}$ \\ ${ }^{1}$ Zaporizhzhya National University, 9, Engineer Preobrazhensky ave., Zaporizhia, 69000, Ukraine
}

\begin{abstract}
Marketing research at an enterprise is carried out by marketing units in order to determine a possible increase in the marketing activity of the enterprise. To identify the strengths and weaknesses of the sales management of the enterprise, the SWOT-analysis method was applied. A matrix of SWOT analysis of company's sales activity was built, which forms squares in the form of a combination of the following factors: "Strengths-Opportunities" (SO), "Strengths-Threats" (ST), "Weaknesses-Possibilities" (WO), "Weaknesses-Threats" (WT). The most significant intersections of the SWOT matrix factors of the analysis were analyzed, and it was proposed to use four types of strategies on their basis. To formalize cause-andeffect relations Ishikawa diagram was used.
\end{abstract}

\section{The presentation of the basic material}

Today, SWOT analysis is one of the research types that allows identifying and structuring the strengths and weaknesses of an enterprise, which makes it possible to determine its potential capacity and possible dangers in marketing activities.

\subsection{SWOT analysis}

The proposed method of conducting a SWOT analysis includes three stages.

At the first stage, the main factors are: Strengths, Weaknesses, Opportunities, Threats [1-3].

The strong sides of an enterprise (Strengths) include competitive environment (S1), availability of intercommodity substitution (S2) and market segmentation (S3).

The weak sides of an enterprise (Weaknesses) include product reliability (W1), product quality (W2), and service (repair) (W3).

The Opportunities determine favorable circumstances that an enterprise can use to gain the advantage, namely projected growth in sales through improving the quality of advertising work (O1), use of digital marketing methods $(\mathrm{O} 2)$ and expanding the circle of regular customers $(\mathrm{O} 3)$.

The Threats of economic entity may include decrease in sales of goods (T1), decrease in the efficiency of an enterprise (T2), and decrease in the production of goods (T3).

The exposed basic factors are tabulated in Table 1.

It should be noted that possibilities from the point of SWOT-analysis are not all those that exist, but only ones, which can be used by an enterprise.
Table 1. SWOT-analysis of enterprise sale activity.

\begin{tabular}{|c|c|}
\hline Strong sides $(S)$ & Weak sides $(W)$ \\
\hline $\begin{array}{l}\text { competitive environment (S1) } \\
\text { intercommodity substitution (S2) } \\
\text { market segmentation (S3) }\end{array}$ & $\begin{array}{l}\text { product reliability (W1) } \\
\text { product quality (W2) } \\
\text { service (repair) (W3) }\end{array}$ \\
\hline Opportunities $(O)$ & Threats $(T)$ \\
\hline $\begin{array}{l}\text { improving the quality of } \\
\text { advertising work }(\mathrm{O} 1) \\
\text { use of digital marketing methods } \\
(\mathrm{O} 2) \\
\text { expanding the circle of regular } \\
\text { customers }(\mathrm{O} 3)\end{array}$ & \begin{tabular}{|} 
decrease in sales of goods \\
(T1) \\
decrease in the efficiency of \\
an enterprise (T2) \\
decrease in the production of \\
goods (T3)
\end{tabular} \\
\hline
\end{tabular}

At the second stage, the matrix of sale activity SWOT-analysis of an enterprise is built (Table 2). The most essential intercrossings of factors which are marked 1 and 0 in case of absence of intercrossings are pointed out in the matrix (graph adjacency matrix). The received matrix allows to show graphically intercrossing factors and to cut off unimportant ones and to build a graph.

Table 2. Matrix of SWOT-analysis of an economic object employees.

\begin{tabular}{|c|c|c|c|c|c|c|c|c|}
\hline \multicolumn{2}{c|}{} & \multicolumn{3}{c|}{ O } & \multicolumn{3}{c|}{ T } \\
\cline { 2 - 8 } \multicolumn{2}{|c|}{} & $\mathbf{O 1}$ & $\mathbf{O 2}$ & $\mathbf{O 3}$ & $\mathbf{T 1}$ & $\mathbf{T 2}$ & $\mathbf{T 3}$ \\
\hline \multirow{3}{*}{$\mathbf{S}$} & $\mathbf{S 1}$ & 1 & 1 & 0 & 1 & 0 & 0 \\
\cline { 2 - 8 } & $\mathbf{S 2}$ & 0 & 1 & 1 & 0 & 0 & 0 \\
\cline { 2 - 8 } & $\mathbf{S 3}$ & 1 & 0 & 0 & 1 & 0 & 0 \\
\hline \multirow{4}{*}{$\mathbf{W}$} & $\mathbf{W 1}$ & 0 & 1 & 1 & 1 & 1 & 1 \\
\cline { 2 - 8 } & $\mathbf{W 2}$ & 0 & 0 & 0 & 1 & 0 & 0 \\
\cline { 2 - 8 } & $\mathbf{W 3}$ & 0 & 0 & 0 & 1 & 0 & 0 \\
\hline
\end{tabular}

The built matrix forms the squares as a combination of the following factors: "Strengths-Opportunities" (S-O), "Strengths-Threats" (S-T), "WeaknessesOpportunities" (W-O), "Weaknesses-Threats" (W-T).

\footnotetext{
Corresponding author: flydaiver@gmail.com
} 
At the third stage, the most substantial intercrossings of factors are analysed.

Thus in the square "Strengths-Opportunities" (S-O) intercrossings of the following factors are important:

S1O1 - improvement of the competitive environment will allow to increase enterprise's sale activity by improving the quality of advertising;

S1O2 - improvement of competitive environment will allow to promote sale activity of an enterprise by applying methods of digital marketing, namely expansion of the target market;

$\mathrm{S} 2 \mathrm{O} 2$ - intercommodity substitution availability causes the necessity of applicating methods of digital marketing, that will result in the expansion of the target market and increase enterprise's sale activity;

S2O3 - intercommodity substitution availability requires from the enterprise additional expenses connected with the expansion of the circle of regular purchasers, which in return is directed at increase of the enterprise's sale activity;

S3O1 - market segmentation is considered as a process of finding optimum segments of market with the purpose of locating goods on the segments taking into account the quality of advertising, which is in its turn directed at the increase of the enterprise's sale activity.

In the square "Strengths-Threats" (S-T) intercrossings of the following factors are important:

S1T1 - underestimation of the competitive environment within the framework of the enterprise can result in decline of commodity sale;

S3T1 - breaking up of potential users at the market into different groups without considering their interests results in decline of commodity sale.

In the square "Weaknesses-Opportunities" (W-O) intercrossings of the following factors are important:

$\mathrm{W} 1 \mathrm{O} 2$ - increase of the commodity reliability allows to extend the target market by the application of the digital marketing methods;

W1O3 - increase of the commodity reliability allows to extend the circle of regular users.

In the square "Weaknesses-Threats" (W-T) intercrossings of the followings factors are important:

W1T1 - the commodity reliability decline reduces the enterprise sale activity;

W1T2 - the commodity low reliability reduces the efficiency of the enterprise;

W1T3 - the commodity low reliability results in decline of producing goods;

W2T1 -the decline of the commodity quality may cause the decline of the commodity sale;

W3T1 - the increase of expenses on service (repair) may result in the commodity sale decline, which will reduce efficiency of the enterprise in return.

On the basis of the conducted analysis of SWOTmatrix squares it is possible to offer the strategy of four types [4]:

- strategies of SO type are strategies of development, which take into account the following: improvement of competitive environment, intercommodity substitution availability causes the necessity of applying methods of the digital marketing with the account of the expansion of the circle of regular purchasers and finding optimum segments of market with the purpose of locating goods at them;

- strategies of type ST are to minimize the underestimation of competitive environment taking into account breaking up regular purchasers at the market;

- strategies of type WO are a weak side management, i.e. the increase of the commodity reliability, that will allow to extend the target market by applying methods of the digital marketing and the circle of regular purchasers; - strategies of type WT are limitations, which take into account the commodity reliability, quality and additional expenses, that can reduce sale activity and efficiency of the enterprise.

Highlighting basic interdependent is groups especially important for the development of marketing strategy.

\subsection{The diagram of Ishikava}

To formalize cause-and-effect relations the diagram of Ishikava is applied $[5,6]$. The diagram of cause-andeffect relations is presented in Fig. 1.

In this diagram sale activity of an enterprise, which influences the efficiency of work is divided by its character into 5 basic groups: competitive environment, market segmentation, advertising quality, digital marketing and quality of commodity. Each factor is presented by a proper fuzzy variable with the range of definition $X$ and by term-set.

Input term-set corresponds to linguistic variables describing marketing characteristics, while sale activity of the enterprise is the output term-set. Each of the set can be presented as $T_{i}^{j}=\left\langle x, \mu_{T_{i}^{j}}(x) \mid x \in\left[x_{\min }, x_{\max }\right]\right\rangle$, where $i=\overline{1, n} ; j=\overline{1, m} ; n-$ is the amount of term-sets, characterizing a certain variable.

The management sale activity of the enterprise is carried out on the basis of the expansion of the target market, related to the factors (by linguistic variables) of competitive environment (T1), market segmentation (T2), advertising quality (T3), digital marketing (T4), quality of commodity (T5) and sale activity (T6).

\subsection{Fuzzy cognitive map}

In this case, the problem of managing sale activity is related to the large ambiguity of influence factors. Therefore enterprise sale resource planning is based on introducing the system as a fuzzy cognitive map [7].

Unlike the traditional cognitive modelling the fuzzy cognitive maps (FCM) are fuzzy oriented graphs [8-10] the nodes of which correspond to fuzzy sets. Therefore the model of FCM is the oriented graph which reflects not only cause-and-effect relation between conceptual objects but also determines the degree of influence of connected concepts.

The fuzzy cognitive map is a graph $G=(T, W)$, where vertex set $T=\left\{T_{i}\right\}$, and $W=\left\{w\left(u_{i}, v_{j}\right)\right\}$ is a set of connections between them. Each vertex is assigned to a concept, characterized by a term-set of linguistic variables, determined by the data tuple. 
Causes

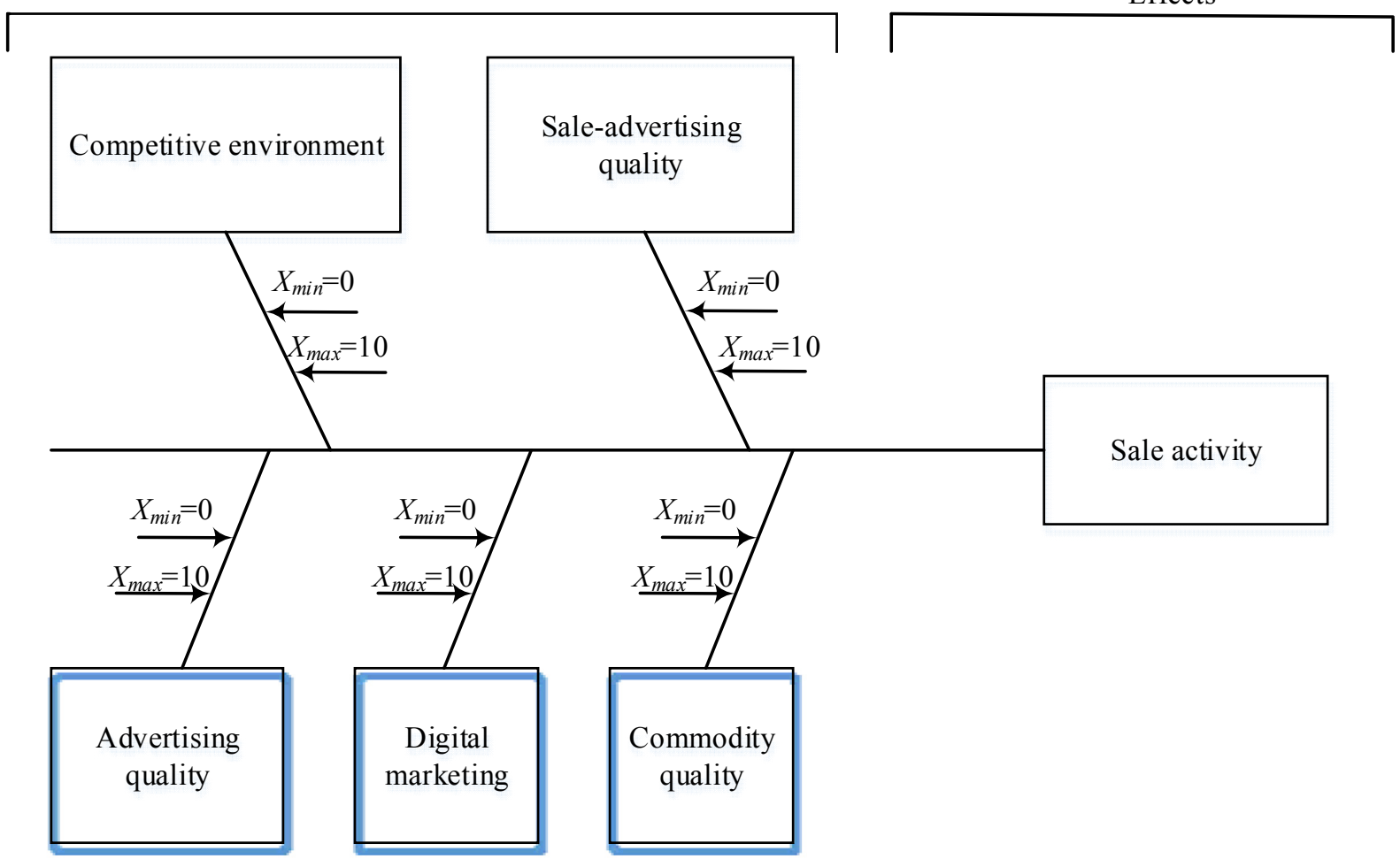

Fig. 1. Diagram of cause-and-effect relation.

Establishing connections between input $\left(\mathrm{T}_{1}, \ldots, \mathrm{T}_{5}\right)$ and output $\left(\mathrm{T}_{6}\right)$ vertex allows to build the fuzzy cognitive map of the enterprise management sale activity process as the oriented graph on the basis of adjacency matrix (Table 2), presented in Fig. 2.

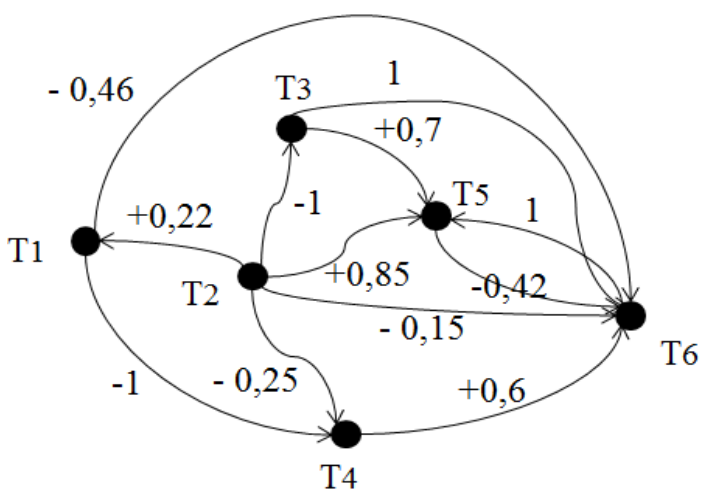

Fig. 2. Model of oriented graph.

However the model of FCM as oriented graph (Fig. 2) suggests that all influences of factors (vertices) on each other are on the interval $[0 ; 1]$. Therefore this model can be presented as a structural model of the enterprise management sale activity process.

A more accurate model can be developed by giving the oriented graph arcs numeric values (weight), that will allow to get a weighted oriented graph. The given weight of arcs can be interpreted as action force of factor, and the sign can be either positive (increase of influence) or negative (diminishing of influence).
The weights of arcs of a weighted oriented graph are determined on the basis of the experts' conclusions on the general laws of the marketing management process (Table 3).

Figure 2 shows a model of a weighted oriented graph constructed by transforming a model of a fuzzy cognitive map into a oriented graph with negative edge weights.

To analyze a model that has the form of a weighted oriented graph (Fig. 2), assumptions are made about the effect of changing the value of a parameter of one vertex on the parameters of other vertices.

These assumptions are called rules for changing the values of the parameters of the vertices. The choice of these rules is a fundamental step in the simulation of an autonomous pulse process, where it is necessary to monitor the spread of initial pulses in the system.

Let the initial values of the parameters at each vertex $\mathrm{T}_{1}, \mathrm{~T}_{2}, \ldots, \mathrm{T}_{6}$, of the digraph shown in Fig. 2 are equal 0.

Each vertex is assumedT $\mathrm{T}_{\mathrm{i}}$ at discrete times $t=0,1,2$, $3, \ldots$ takes value $v_{i}(t)$.

Derived value $v_{i}(t+1)$ determined by information about increasing or decreasing its values of the vertices adjacent to the vertex $\mathrm{T}_{i}$ at time $t$.

Change $p_{i}(t)$, called impulse, given by the difference in weights in the $i$-th vertex: $v_{i}(t)-v_{i}(t-1)$, at $t>0$.

Changes in the values of the sales process of the enterprise in a weighted oriented graph, has the following form:

$$
v_{j}(\mathrm{t}+1)=v_{j}(\mathrm{t})+\sum_{\mathrm{i}=1}^{\mathrm{n}} w\left(u_{i}, v_{j}\right) p_{i}(t),
$$

where $v_{j}(t)$ - vertex weight $j$ at time $t, w\left(u_{i}, v_{j}\right)-\operatorname{arc}$ weight of $u_{i}$ to $v_{j}$ at time $t$. 
Table 3. Weights of curve of a scales oriented graph.

\begin{tabular}{|c|c|c|}
\hline curve & weight & Conclusions on the choice of scales \\
\hline$\left(\mathrm{T}_{1}, \mathrm{~T}_{6}\right)$ & $-0,46$ & $\begin{array}{l}\text { With the increasing influence of the } \\
\text { competitive environment, according to expert } \\
\text { data, the magnitude of the impact is }-0.46 \text {. }\end{array}$ \\
\hline$\left(\mathrm{T}_{2}, \mathrm{~T}_{1}\right)$ & $+0,22$ & $\begin{array}{l}\text { With the use of tools, market segmentation, } \\
\text { according to expert data, the magnitude of the } \\
\text { impact is }+0.22 \text {. }\end{array}$ \\
\hline$\left(\mathrm{T}_{2}, \mathrm{~T}_{3}\right)$ & -1 & $\begin{array}{l}\text { With the involvement of tools market } \\
\text { segmentation, the quality of advertising work is } \\
\text { changed to }-1 \text {. }\end{array}$ \\
\hline$\left(\mathrm{T}_{1}, \mathrm{~T}_{4}\right)$ & -1 & $\begin{array}{l}\text { Increasing the influence of the competitive } \\
\text { environment allows us to establish a unit value } \\
\text { of the weight of this arc. }\end{array}$ \\
\hline$\left(T_{2}, T_{4}\right)$ & $-0,25$ & $\begin{array}{l}\text { Increasing investment in market segmentation } \\
\text { tools leads to a decrease in the quality of digital } \\
\text { marketing, according to expert data, the arc } \\
\text { size will be }-0.25 \text {. }\end{array}$ \\
\hline$\left(\mathrm{T}_{2}, \mathrm{~T}_{5}\right)$ & $+0,85$ & $\begin{array}{l}\text { With an increase in market segmentation, the } \\
\text { quality of goods grows, according to expert } \\
\text { data, the weight of this arc will be }+0.85\end{array}$ \\
\hline$\left(\mathrm{T}_{2}, \mathrm{~T}_{6}\right)$ & $-0,15$ & $\begin{array}{l}\text { An increase in market segmentation leads to a } \\
\text { decrease in sales activity. According to expert } \\
\text { data, the weight of the arc is }-0.15 \text {. }\end{array}$ \\
\hline$\left(T_{3}, T_{5}\right)$ & $+0,7$ & $\begin{array}{l}\text { The increase in the quality of the goods due to } \\
\text { the increase in the quality of advertising work. } \\
\text { According to expert data, the arc weight will be } \\
+0.7 \text {. }\end{array}$ \\
\hline$\left(\mathrm{T}_{3}, \mathrm{~T}_{6}\right)$ & +1 & $\begin{array}{l}\text { The increase in the quality of advertising work, } \\
\text { causes an increase in sales activities. }\end{array}$ \\
\hline$\left(\mathrm{T}_{4}, \mathrm{~T}_{6}\right)$ & $+0,6$ & $\begin{array}{l}\text { As digital marketing grows, so does sales. } \\
\text { According to expert data, the arc weight will be } \\
+0.6 \text {. }\end{array}$ \\
\hline$\left(\mathrm{T}_{5}, \mathrm{~T}_{6}\right)$ & $-0,42$ & $\begin{array}{l}\text { According to experts, the weight of the arc will } \\
\text { be about }-0,42 \text {. }\end{array}$ \\
\hline $\left.\mathrm{T}_{5}\right)$ & +1 & $\begin{array}{l}\text { According to experts, the weight of the arc will } \\
\text { be about } 1\end{array}$ \\
\hline
\end{tabular}

Since the pulse in $j$-th vertex: $v_{j}(t+1)-v_{j}(t)=p_{j}(t)$, then from the expression (1) the value of the pulse can be written in the following form:

$$
p_{j}(t)=\sum_{\mathrm{i}=1}^{\mathrm{n}} w\left(u_{i}, v_{j}\right) p_{i}(t) .
$$

In the digraph in Fig. 2 we study the dynamics of five simple impulse processes, each of which begins independently of the other at the vertex $T_{1}, T_{2}, \ldots, T_{5}$ corresponding to the sales factor.

Then the matrix of weights of NKK will have the following form Table 4 .

Table 4. FCM weights matrix.

\begin{tabular}{|c|c|c|c|c|c|c|}
\hline & $\mathrm{T}_{1}$ & $\mathrm{~T}_{2}$ & $\mathrm{~T}_{3}$ & $\mathrm{~T}_{4}$ & $\mathrm{~T}_{5}$ & $\mathrm{~T}_{6}$ \\
\hline $\mathrm{T}_{1}$ & 0,00 & 0,00 & 0,00 & -1 & 0,00 & $-0,46$ \\
\hline $\mathrm{T}_{2}$ & 0,22 & 0,00 & -1 & $-0,25$ & 0,85 & $-0,15$ \\
\hline $\mathrm{T}_{3}$ & 0,00 & 0,00 & 0,00 & 0,00 & 0,7 & 1 \\
\hline $\mathrm{T}_{4}$ & 0,00 & 0,00 & 0,00 & 0,00 & 0,00 & 0,6 \\
\hline $\mathrm{T}_{5}$ & 0,00 & 0,00 & 0,00 & 0,00 & 0,00 & $-0,42$ \\
\hline $\mathrm{T}_{6}$ & 0,0 & 0,00 & 0,00 & 0,00 & 1,00 & 0,00 \\
\hline
\end{tabular}

Thus, we have five vectors of initial impulses:

$$
\begin{aligned}
& \boldsymbol{p}_{1}\left(\begin{array}{l}
0 \\
0
\end{array}\right)\left(\begin{array}{llllll}
1 & 0 & 0 & 0 & 0 & 0
\end{array}\right) \text {, } \\
& \boldsymbol{p}_{2}\left(\begin{array}{l}
0 \\
0
\end{array}\right)\left(\begin{array}{llllll}
0 & 1 & 0 & 0 & 0 & 0
\end{array}\right), \\
& \boldsymbol{p}_{3}\left(\begin{array}{l}
0 \\
0
\end{array}\right)\left(\begin{array}{llllll}
0 & 0 & 1 & 0 & 0 & 0
\end{array}\right) \text {, }
\end{aligned}
$$

$$
\begin{aligned}
& \boldsymbol{p}_{4}(0)=\left(\begin{array}{llllll}
0 & 0 & 0 & 1 & 0 & 0
\end{array}\right), \\
& \boldsymbol{p}_{5}\left(\begin{array}{l}
0 \\
0
\end{array}\right)\left(\begin{array}{llllll}
0 & 0 & 0 & 0 & 1 & 0
\end{array}\right) .
\end{aligned}
$$

Vertex $\mathrm{T}_{6}$, indicating the level of marketing activities of the enterprise, is targeted at each stage of this process. The results of calculations of the dynamics of the pulse at the vertex $T_{6}$ at different initial vertices of simple impulse processes are presented in Table 5 .

Table 5. Dynamics pulse at the vertex $\mathrm{T}_{6}$ at different initial impulses.

\begin{tabular}{|c|c|c|c|c|c|}
\hline$t$ & $p_{1}(t)$ & $p_{2}(t)$ & $p_{3}(t)$ & $p_{4}(t)$ & $p_{5}(t)$ \\
\hline 0 & 0 & 0 & 0 & 0 & 0 \\
\hline 1 & $-0,4600$ & $-0,15$ & 1 & 0,6 & $-0,42$ \\
\hline 2 & $-0,6000$ & $-1,608$ & $-0,294$ & 0 & 0 \\
\hline 3 & 0,1932 & 0,225 & $-0,42$ & $-0,252$ & 0,1764 \\
\hline 4 & 0,252 & 0,6754 & 0,1235 & 0 & 0 \\
\hline 5 & $-0,08114$ & $-0,095$ & 0,1764 & 0,1058 & $-0,074$ \\
\hline
\end{tabular}

Here $p_{i}(t)$ denotes the value of the pulse at the vertex $\mathrm{T}_{6}$ at the moment $\mathrm{t}$ of the action of a simple impulse process with the beginning at the $i$-th vertex.

Graph simulation of the dynamics of the pulse at the top $\mathrm{T}_{6}$ with the corresponding impulse effect is presented in Fig. 3.

Thus, as a result of modeling the sales activity of an enterprise with a pulse effect on a weighted oriented graph (Fig. 3) and modeling the dynamics of weight, it has been established (Fig. 4) that improving the quality of advertising work (vertex $\mathrm{T}_{3}$ ) and applying digital marketing (vertex $\mathrm{T}_{4}$ ) lead to higher levels of marketing activities of the enterprise.

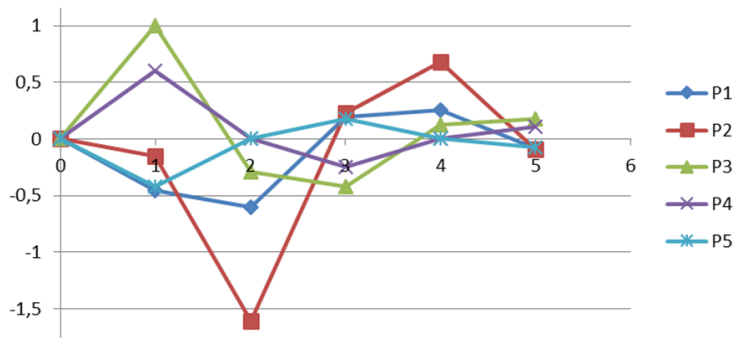

Fig. 3. Modeling the sales activity of an enterprise with a pulse effect on a weighted oriented graph.

The results of calculations of the dynamics of weight at the vertex $T_{6}$ at different initial pulses are presented in Table 6 where $v_{i}(t)$ denotes the weight value of the vertex $\mathrm{T}_{6}$ at the moment $t$ of the action of a simple impulse process with the beginning at the $i$-th vertex.

Table 6. The results of calculations of the weight of the vertex $\mathrm{T}_{6}$ with different initial impulses.

\begin{tabular}{|c|c|c|c|c|c|}
\hline$t$ & $v_{1}(t)$ & $v_{2}(t)$ & $v_{3}(t)$ & $v_{4}(t)$ & $v_{5}(t)$ \\
\hline 0 & 0 & 0 & 0 & 0 & 0 \\
\hline 1 & $-0,4600$ & $-0,15$ & 1 & 0,6 & $-0,42$ \\
\hline 2 & $-1,0600$ & $-1,758$ & 0,706 & 0,6 & $-0,42$ \\
\hline 3 & $-0,8668$ & $-1,533$ & 0,286 & 0,348 & $-0,244$ \\
\hline 4 & $-0,6148$ & $-0,858$ & 0,4095 & 0,348 & $-0,244$ \\
\hline 5 & $-0,69594$ & $-0,952$ & 0,5859 & 0,4538 & $-0,318$ \\
\hline
\end{tabular}

Graph modeling of the dynamics of weight at the vertex $T_{6}$ with a pulse effect is presented in Fig. 4. 


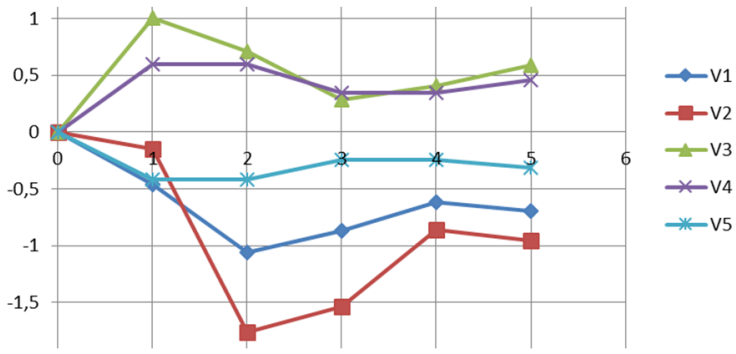

Fig. 4. Modeling the assessment of the marketing activity of the enterprise (vertex $\mathrm{T}_{6}$ ) with a pulse effect on a weighted oriented graph.

The corresponding lines in Fig. 4 have an increasing trend in the observed time interval. Perturbations at the vertices: $\mathrm{T}_{1}$ - "competitive environment", $\mathrm{T}_{5}$ - "quality of commodity", $\mathrm{T}_{2}$ - "market segmentation" lead to weight changes at the vertex $\mathrm{T}_{6}$.

This means that when building strategies for managing the marketing activities of an enterprise, attention should be paid to the competitive environment, product quality and market segmentation.

\section{Conclusions}

Thus, the model of intercrossings of strong and weak sides was built on the basis of SWOT-analysis; it is suggested to use effective strategies for the corresponding intercrossings on the basis of the model. Recommendation for the use of strategies of four types for development of company marketing were developed. The diagram of Ishikava reflecting cause-and-effect relation of sale activity of enterprise is built.

On the basis of the received data it is possible to build the model of fuzzy cognitive map, that can result in determining how the modification of factors will influence the sale under different initial conditions and it is possible to analyse interrelation of advertising quality, application of the digital marketing with the change of the enterprise sale activity level.

\section{References}

1. Churkina, V., Suhova, O.V.: Primenenie metoda SWOT analiza $\mathrm{v}$ issledovanii sistemyi upravleniya organizatsii. Obschestvo i tsivilizatsiya: Tendentsii i perspektivyi razvitiya sovremennogo obschestva $\mathrm{V}$ XXI veke, Voronezh (2016)

2. Mikuláš, L.: Mathematical Optimization and Economic Analysis. Springer, Vienna (2009)

3. Shipilov, N.Yu., Koneva, A.I.: Provedenie SWOTanaliza $\mathrm{V}$ nekommercheskoy organizatsii. Tavricheskiy obozrevatel, Yalta (2017)

4. Ansoff, H.I.: Strategic Management. Springer, New York (2007)

5. Samartseva, A.V., Belyakova, E.V.: Ispolzovanie diagrammyi Isikavyi $\mathrm{V}$ tselyah formirovaniya gorodskoy logisticheskoy infrasturkturyi. Aktualnyie problemyi aviatsii i kosmonavtiki, Krasnoyarsk (2013)
6. Logunova, O.E.: Primenenie prichinno-sledstvennoy diagrammyi Isikavyi $\mathrm{v}$ reputatsionnom menedzhmente. Nauchnyie issledovaniya, Ivanovo (2015)

7. Paklin, N.B.: Nechetko-kognitivnyiy podhod k upravleniyu dinamicheskimi sistemami. Iskusstvennyiy intellect, Donetsk (2003)

8. Volkov, V.Yu., Volkova, V.V.: Nechetkaya kognitivnaya karta kak model slozhnoy sistemyi upravleniya. Izvestiya TulGu. Tehnicheskie nauki, Tula (2017)

9. Ivanovich, V.V., Savina, I.A., Sharipova, I.I.: Postroenie nechetkih kognitivnyih kart dlya analiza i upravleniya informatsionnyimi riskami vuza. Vestnik Ufimskogo gosudarstvennogo aviatsionnogo tehnicheskogo universiteta, Ufa (2008)

10. Evstafev, G.A.: Nechyotkie kognitivnyie kartyi primenitelno $\mathrm{k}$ upravleniyu riskami informatsionnoy bezopasnosti. Izvestiya Yuzhnogo federalnogo universiteta. Tehnicheskie nauki, Taganrog (2009) 